\title{
O FIM DA POBREZA EXTREMA
}

\author{
Por Rosa Maria Vieira \\ Professora da FGV-EAESP e do departamento de Economia da FEA-PUC-SP \\ E-mail: rvieira@fgvsp.br
}

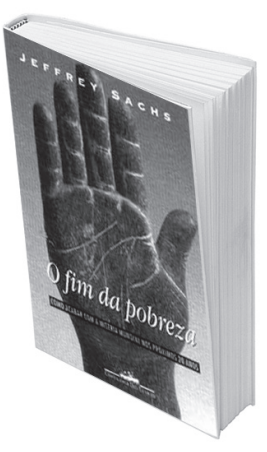

\section{O FIM DA POBREZA: COMO ACABAR COM A MISÉRIA MUNDIAL NOS PRÓXIMOS VINTE ANOS}

De Jeffrey Sachs

São Paulo: Companhia das Letras, 2005. 449 p.

O economista Jeffrey Sachs tem em seu currículo o plano econômico que pôs fim à hiperinflação na Bolívia de Paz Estensoro, a participação no processo que abriu a Polônia e a União Soviética à economia de mercado, a direção do Instituto Terra na Universidade Columbia e, nos últimos anos, a assessoria especial a Kofi Annan na ONU. E como é de se esperar de um "homem de ação", ligado a organismos internacionais, realizou visitas a mais de uma centena de países nas duas últimas décadas na condição de problem-solver.

Seu livro traz o relato dessas experiências e, sobretudo, da inflexão em sua trajetória como economista liberal que acabou se tornando um crítico das regras da Organização Mundial do Comércio e da política do Fundo Monetário Internacional e do Banco Mundial para com os países pobres da periferia do capitalismo. O foco central, porém, é seu projeto para acabar com a pobreza extrema no mundo até 2025.
Recheada de gráficos, dados estatísticos e mapas, a publicação não oferece dificuldades para o leitor não especializado em economia. Sua linguagem é simples e direta, em estilo jornalístico, o que permite que se avance na leitura sem dificuldade. Discussão conceitual, somente a indispensável para expor seus diagnósticos e divulgar seu projeto. Acompanhado de um índice remissivo, que facilita a consulta localizada de dados e informações, o livro traz também prefácios de Bono, vocalista da banda de rock U2, e para a edição brasileira, do embaixador Rubens Ricúpero.

Cinco dos 18 capítulos do livro são dedicados ao relato de sua participação no plano de combate à hiperinflação boliviana, de suas experiências no processo de estabelecimento da economia de mercado na Polônia (198990). Segue-se seu envolvimento com a transição capitalista na Rússia ao final da era Gorbatchov, e sua atuação como consultor das autoridades chinesas para problemas de desenvolvimento. Relata ainda suas análises sobre as reformas de mercado na Índia. Mas seu pragmatismo militante (ou "voluntarismo", como quer Ricúpero) de alto funcionário das Nações Unidas, imbuído de obstinada crença no poder da razão e da vontade reformadora, só aflora plenamente quando se volta para o relato das experiências e da proposição de políticas para a redução da pobreza dos países que a ONU classifica como least developed countries (LDCs).

Sachs, que distingue três graus de pobreza - a relativa, a moderada e a extrema -, está preocupado com a pobreza extrema que atinge um sexto da humanidade, localizada na periferia subdesenvolvida, que não pode satisfazer as mínimas necessidades de sobrevivência, sofrendo de fome crônica e sem acesso a saneamento básico, educação e saúde. Valendo-se de dados fornecidos pelo Banco Mundial, Sachs localiza na África subsaariana a extrema pobreza que, nas últimas décadas, 
cresceu em números absolutos, associada ao pesadelo da aids e ao genocídio sistemático praticado por corruptos Estados ditatoriais.

Os projetos idealizados por Sachs se destinam às nações vítimas do que denomina "armadilha da pobreza": situação em que os países de baixíssima renda per capita (US\$ 1 ou US\$ 2 ao dia), sem acesso ao comércio internacional e aos mercados de financiamento, consomem praticamente tudo o que produzem, pouco sobrando para o Estado investir em serviços básicos e contribuir para a geração de investimentos produtivos e capital fixo. Numa formulação que lembra o "círculo vicioso da pobreza" de Gunnar Myrdal, a idéia é a de que nessas regiões a capacidade produtiva está longe de acompanhar o crescimento da população, fazendo com que a poupança e o investimento se atrofiem continuamente, numa causação circular imobilizadora.

Partindo do pressuposto de que a ciência econômica aprendida nos centros universitários dos países ricos está longe de permitir a compreensão da dinâmica perversa da pobreza extrema, Sachs faz um mea-culpa teórico e propõe a retificação da economia do desenvolvimento de modo que se assemelhe à medicina moderna. Isso implica que as intervenções do Banco Mundial e do FMI na periferia miserável deixem de ser desastrosas. Em lugar do conhecido receituário de austeridade e ajustes fiscais e orçamentários, são recomendados outros procedimentos para os países miseráveis em crise: os da "economia clínica".

Quando se refere à adoção da economia clínica, Sachs tem em mente a substituição das políticas neoliberais postas em prática pelos organismos internacionais na "Era do Ajuste Estrutural", nome pelo qual se refere ao período da virada conservadora de Ronald Reagan, nos Estados Unidos, e de Margaret Thatcher, na Grã-Bretanha.
No lugar das avaliações generalizantes, que vêem sempre má governança, gastos públicos em demasia e excesso de propriedade estatal por trás de todas as crises econômicas, propõe o "diagnóstico diferencial seguido de um tratamento apropriado". Mas, o que Sachs entende por "diagnóstico diferencial"?

Entre as categorias essenciais do diagnóstico diferencial está a determinação das dimensões reais da miséria, o mapeamento dos principais fatores de risco que podem exacerbar a pobreza, o levantamento dos custos dos negócios em regiões afetadas pela falta de infra-estrutura, por barreiras comerciais e pela carência de investimentos em capital humano, os estudos sobre a estrutura fiscal e orçamentária, a investigação da interface da sociedade com o ambiente físico, a avaliação dos padrões de governança e das possíveis barreiras culturais ao desenvolvimento econômico e, também, a análise da geopolítica das relações econômicas e de segurança com o resto do mundo.

Para romper o círculo vicioso da pobreza extrema, o diagnóstico diferencial é apenas o ponto de partida, pois o aspecto central é a ajuda externa, uma rede global de cooperação coordenada pelos países ricos que possibilite aos miseráveis colocar "um pé na escada do desenvolvimento". Sem essa ajuda, a armadilha da pobreza nunca poderá ser desarmada, pois o baixo nível de capital por pessoa, nesses países, tende a cair de geração a geração, numa escalada perversa e inexorável.

Para Sachs, as nações mais pobres precisam, basicamente, de cinco modalidades de capital: capital humano (saúde, nutrição e treinamento), capital empresarial (máquinas, instalações, transporte), infra-estrutura (estradas, energia, água, saneamento), capital natural (terras cultiváveis, solos saudáveis), capital público insti- tucional (leis comerciais, sistemas judiciais, serviços públicos) e capital de conhecimento (know-how científico e tecnológico). Para que isso se viabilize, o diagnóstico diferencial precisa, necessariamente, estar acompanhado por planos de investimento financeiro, de doadores e de gestão pública, do cancelamento das dívidas externas dos miseráveis e do indispensável esforço interno de combate à corrupção e melhoria da governança nacional.

Quanto custaria aos países ricos ajudar a periferia a romper o círculo vicioso da pobreza? Segundo os cálculos de Jeffrey Sachs, nada além dos limites já empenhados pelo centro desenvolvido: $0,7 \%$ do produto nacional bruto do mundo de alta renda, meros US\$ 0,07 de cada US\$ 10 de renda, ou seja, menos de $1 \%$ da renda dos muito ricos. Sem dúvida é muito pouco frente à extraordinária tragédia humana da África contemporânea, um dos legados do neocolonialismo europeu do século XIX.

Para os que possam vê-lo como pouco mais que um otimista bem intencionado, Jeffrey Sachs tem uma resposta:

Embora os manuais de introdução
à economia preguem o individualis-
mo e os mercados descentralizados,
nossa segurança e prosperidade de-
pendem pelo menos igualmente das
decisões coletivas de lutar contra a
doença, promover a boa ciência e
a difusão da educação, proporcio-
nar infra-estrutura crítica e agir em
uníssono para ajudar os mais mise-
ráveis. (p. 29).

Ficam alertados os desavisados defensores da exclusividade do mercado como fautor de sociabilidade humana de que há riscos pelo abandono dos que perderam a corrida pela cumulação para aqueles que na repartição da riqueza ficaram com a abundância e com o desperdício. 